\title{
A comparison of policies to reduce the methane emission intensity of smallholder dairy production in India
}

Article

Accepted Version

Creative Commons: Attribution-Noncommercial-No Derivative Works 4.0

York, L., Heffernan, C. and Rymer, C. (2017) A comparison of policies to reduce the methane emission intensity of smallholder dairy production in India. Agriculture, Ecosystems and Environment, 246. pp. 78-85. ISSN 0167-8809 doi: https://doi.org/10.1016/j.agee.2017.05.032 Available at https://centaur.reading.ac.uk/70792/

It is advisable to refer to the publisher's version if you intend to cite from the work. See Guidance on citing.

To link to this article DOI: http://dx.doi.org/10.1016/j.agee.2017.05.032

Publisher: Elsevier

All outputs in CentAUR are protected by Intellectual Property Rights law, including copyright law. Copyright and IPR is retained by the creators or other copyright holders. Terms and conditions for use of this material are defined in the End User Agreement.

www.reading.ac.uk/centaur 
Central Archive at the University of Reading

Reading's research outputs online 
1 A comparison of policies to reduce the methane emission intensity of smallholder dairy

2 production in India.

3 L. York ${ }^{\mathrm{a}}$, C. Heffernan ${ }^{1, \mathrm{a}}$ and C. Rymer $^{\mathrm{b}}$

$4 \quad{ }^{a}$ Livestock Development Group (LDG), Faculty of Life Sciences, University of Reading,

5 Reading $R G 66 A R, U K$

$6 \quad{ }^{b}$ Sustainable Agriculture and Food Research Division, Faculty of Life Sciences, University of

$7 \quad$ Reading, Reading RG6 6AR, $U K$

$8{ }^{1}$ Current address: School of Veterinary Sciences, University of Bristol, Langford House,

9 Langford, Bristol, BS40 5DU

10 Corresponding author: Luke York. Email: luke_york@live.com.au,

11 1.e.york@pgr.reading.ac.uk (L. York)

12 Abstract

13 Within the dairy sector, the effects of climate change are particularly diverse as cows are

14 affected by, and a significant contributor to climate change. With a burgeoning body of work indicating the importance of livestock's contribution to climate change (via Greenhouse Gas (GHG) emissions), the dairy sector will increasingly be targeted for emission reduction. Yet, gaps in knowledge remain as to the effectiveness of interventions in achieving emission reductions. The investigation examines two high-profile Indian policies to evaluate their effectiveness in reducing the methane emission intensity of milk production in Odisha, India.

20 Selected policies included the installation of smallscale anaerobic digesters and the control of 21 Foot and Mouth Disease (FMD). The interventions were evaluated at the cow level informed by data collected from 115 smallholder dairy producers in Puri $(n=31)$ and Khurda $(n=84)$ districts in Odisha, India. The installation of an anaerobic digester was found to increase methane emission intensity by 4.41-5.01\%. Control of FMD reduced methane emission intensity by $3.68-12.95 \%$ depending on the infection scenario considered. The findings highlight the importance of contextually relevant and multi-sectoral approaches to mitigation as the increase in methane emission intensity following anaerobic digester installation represents movement of emissions from the energy sector into the dairy sector where mitigation is inherently more complex. Thus, the long-term usefulness of anaerobic digester installation as a mitigation strategy is limited. 
Keywords: Climate change, India, Odisha, anaerobic digester, Foot and Mouth Disease.

\section{Introduction}

The livestock sector is a key feature of the Indian economy contributing approximately $4.1 \%$ to GDP in 2012-2013 (Government of India, 2014a). The dairy sector is the most important component of the Indian livestock sector contributing $65.1 \%$ of the total value (Government of India, 2014b). The Indian dairy sector is the largest in the world composed of approximately 44.5 million milking cows (Government of India, 2014b) representing 16.7\% of the world's dairy cattle population (FAO, 2013).

The Indian dairy sector is primarily composed of smallholders who are responsible for $70 \%$ of India's bovine (cattle and buffalo) population (Datta et al., 2015). Within India, smallholder operations are characterized by small landholdings ( $<2 \mathrm{ha})$ and small herd sizes (an average of 0.89 female cattle per household) of low productivity (Datta et al., 2015). The average daily milk production of India's crossbred cows is $7.0 \mathrm{~kg} / \mathrm{cow}$ and $2.4 \mathrm{~kg} / \mathrm{cow}$ for indigenous cows (Government of India, 2014b). However, a great deal of variability is noted between states. For example, Odisha has lower average levels of milk production at $6.2 \mathrm{~kg} / \mathrm{cow}$ per day for crossbred and $1.5 \mathrm{~kg} / \mathrm{cow}$ per day for indigenous cows (Government of India, 2014b).

Due to constraints associated with feeding, breeding, health and management (Government of India, 2012b) the low levels of milk production make the Indian dairy sector one of the most greenhouse gas (GHG) emission intensive (Gerber et al., 2011). Indian estimates of emission intensity (see Swamy and Bhattacharya, 2006; Jha et al., 2011; Patra, 2012) are considered partial estimates as they are not weighted to consider the associated dairy population (such as; replacement heifers, cull calves, etc.) and focus heavily on methane $\left(\mathrm{CH}_{4}\right)$ emission from enteric fermentation and manure management practices. Nitrous oxide emissions receive little attention due to their limited importance within the smallholder sector (Swamy and Bhattacharya, 2006; Patra, 2012). Similarly, carbon dioxide produced during respiration is excluded as this represents the return of photosynthesized carbon dioxide to the atmosphere and does not affect net carbon dioxide emissions from livestock (IPCC, 2006a). Indeed, emission inventories from India's National Communications to the United Nations Framework Convention on Climate Change (UNFCCC) are considered complete emission estimates (see Government of India, 2004, 2012a). However, these reports do not consider the emission intensity of milk production. 
Indian crossbred dairy cows are estimated to produce between 0.53 and $0.70 \mathrm{~kg} \mathrm{CO}_{2}$ equivalents/kg of milk (Swamy and Bhattacharya, 2006; Jha et al., 2011). Indigenous Indian cattle have a higher methane emission intensity producing between 1.03 and $2.40 \mathrm{~kg} \mathrm{CO}_{2}$ equivalents/kg of milk (Swamy and Bhattacharya, 2006; Jha et al., 2011). In terms of Fat and Protein Corrected Milk (FPCM), the emission intensity of indigenous and crossbred milk production was found to $6.5 \mathrm{~kg} \mathrm{CO} 2$ equivalents $/ \mathrm{kg}$ of FPCM milk and $1.4 \mathrm{~kg} \mathrm{CO}_{2}$ equivalents/kg of FPCM milk, respectively (Patra, 2012). Although the value offered by Patra (2012) is a more complete estimate of emission intensity as it is weighted to consider the associated dairy population, the author includes all cattle (including draft animals) within the dairy sector. In doing so, the emission intensity offered is likely to be an overestimation.

Indian estimates of emission intensity appear comparable to the emission intensity estimates from northern production systems. For example, in the United states Capper et al., (2009) found an emission intensity of $1.35 \mathrm{~kg} \mathrm{CO}_{2}$ equivalents/ $\mathrm{kg}$ of milk for modern (year 2007) intensive methods of production. Similarly, in the United Kingdom Foster et al., (2007) found emission intensity to be $1.14 \mathrm{CO}_{2}$ equivalents $/ \mathrm{kg}$ of milk. However, these authors employed a Life Cycle Assessment (LCA) approach which is common practice for dairy sector emission estimates in the global north (see FAO, 2010; Kristensen et al., 2011; Opio et al., 2013). The LCA approach provides a more comprehensive estimate of emission intensity as the emissions associated with feed production and processing are included (in addition to enteric and manure management sources) (FAO, 2010). Thus, it is likely that the emission intensity of Indian milk production will be significantly larger should a LCA approach be used. Using a LCA approach, Gerber et al., (2013) estimated the average emission intensity of South Asian integrated crop-livestock systems to be $5.5 \mathrm{~kg} \mathrm{CO} 2$ equivalents $/ \mathrm{kg}$ of milk. The global average was found to be $2.7 \mathrm{~kg} \mathrm{CO}_{2}$ equivalents $/ \mathrm{kg}$ of milk (Gerber et al., 2013).

It is inevitable that the Indian dairy sector will be targeted for GHG emission reduction due to the high emission intensity and sheer size of the sector. However, achieving emission reductions from the Indian dairy sector is inherently complex due to the contributions livestock make to the country's economy and food security. As such, India is currently without any dairy sector GHG emission mitigation policies. Yet, the Indian government policy position can be gleaned from existing documents which indicate emission reductions must be achieved without reducing productivity or dairy cattle population size (Government of India, 2011b). 
98 Internationally, authors have begun to question whether reductions in GHG emission can be achieved without a reduction in livestock population. For example, Webb et al., (2014) found that achieving a $20 \%$ reduction in UK livestock sector GHG emissions was not possible without reducing output (or exporting emissions overseas). Similarly, reduced stocking rates were required to reduce emissions from the New Zealand dairy sector (Adler et al., 2013; Doole, 2014). Thus, achieving emission reductions without reducing the national herd size represents a significant challenge. Indeed, the development of a low emission dairy sector under the guise of sustainable intensification may be possible (Gerber et al., 2011, 2013; Herrero et al., 2015). However, intensification is particularly challenging within India due to chronic feed shortages (Government of India, 2012b, 2013). As such, questions remain as to whether emission intensity can be reduced to the level required to offset the increases in emission expected in response to increasing demand (Delgado et al., 1999; Pica-Ciamarra and Otte, 2009).

A range of existing Indian policies are likely to have an impact on the GHG emission intensity of the dairy sector. In this circumstance, policymakers could reconsider existing policies within an overarching climate change framework. For example, over the past 30 years, the installation of smallscale anaerobic digesters has been a government priority. By the end of 2017, 5.6 million smallscale anaerobic digesters will have been installed with over 6.5 million installations expected by 2022 (Government of India, 2011c). However, the effect of anaerobic digesters on dairy sector GHG emissions is largely unknown as the energy sector has been the focus of research. As a result, no studies have been undertaken to evaluate the impact of anaerobic digesters on dairy sector emissions, despite system leakage being identified as a potential concern (e.g. Bruun et al., 2014).

122 Disease control is a stand-alone priority within Indian livestock policy (Government of India, 2013). From a mitigation perspective, disease control provides significant co-benefits as improved productivity (and reduced cull rates) will reduce GHG emissions (Hospido and Sonesson, 2005). Foot and Mouth Disease (FMD) could be targeted as significant resources

126 have been allocated to its control. During 2013-2014, the Indian government spent Rs. 2.5 127 billion on FMD control (Government of India, 2014b). It is estimated that the Indian bovine 128 (cattle and buffalo) population receive 150 million doses of FMD vaccination annually 129 (Knight-Jones and Rushton, 2013). Despite such investments India has the world's highest 
incidence rate (along with China) at 3.39\% (Knight-Jones and Rushton, 2013). During 2013,

131 it is estimated that 75255 bovines (including cattle and buffalo) were affected by the disease, resulting in the death of 7336 individuals (Government of India, 2014b). However, such infection levels likely underestimate the importance of the disease. For example, at a prevalence of 3.39\% (Knight-Jones and Rushton, 2013) assuming a herd size of 44.5 million (Government of India, 2014b) it would be expected that approximately 1.5 million dairy cows would be affected (assuming no vaccination program is in place). Such a figure is more commensurate to the annual median cost of production losses (i.e. Rs. 126 billion (KnightJones and Rushton, 2013)).

Therefore, the aim of the investigation was to compare two policies to determine their

140 effectiveness in reducing the GHG emission intensity of milk production in Odisha, India.

141 The installation of smallscale anaerobic digesters and the control of FMD in dairy cattle were selected due to their high profile and importance within Indian livestock policy. Indeed, a range of Indian policies will also affect the emission intensity of milk production. However,

144 the selected policies were locally relevant and had been implemented widely throughout the research sites. The interventions were evaluated at the herd level informed by data collected

146 from 115 smallholder dairy producers in Puri $(\mathrm{n}=31)$ and Khurda $(\mathrm{n}=84)$ districts of Odisha, 147 India.

\subsection{Household-level sampling and data collection}

150 Villages were randomly selected within a $40 \mathrm{~km}$ area of the Odisha state capital,

151 Bhubaneswar. The villages were within a high potential dairying zone which was

152 characterized by sufficient water, market access, and relatively reliable animal health

153 infrastructure. Cattle owning households $(\mathrm{n}=115)$ were purposively sampled from Puri $(\mathrm{n}=31)$

154 and Khurda ( $\mathrm{n}=84$ ) districts. Local community leaders helped to identify cattle owning

155 households. A portion ( $\mathrm{n}=35)$ of the sampled households were found to be affected by FMD

156 in the 12-months preceding the interview. A total of 47 crossbred Jersey cows were identified

157 as being affected. Surveys were conducted in the local language (Oriya) with responses being

158 translated into English at the time of the interview. A voice recorder ensured all interviews

159 were recorded verbatim. Interviews were transcribed into Microsoft Access 2010. 
161 Farmers were asked a range of questions detailing their dairy operation. Demographic and socio-economic information of sampled households is provided in York et al. (2016). For each cow, farmers were asked to detail milk production (L/cow/day) for each month of the

164 12-month period preceding the interview. A milk density factor of 1.033 (International Farm

165 Comparison Network, 2015) was used to convert milk yields into $\mathrm{kg} / \mathrm{day}$. Where possible, 166 farmer responses were corroborated with farm-level records of milk sales provided by local 167 milk collection agents. The records contained sales information only. It was necessary to rely 168 on farmer recall to estimate the quantity of milk kept for household consumption. The milk 169 yield of each sampled cow was not directly measured as it was not possible for the research 170 team to be present in each village at the time of milking (morning and evening) throughout 171 the entire lactation period.

172 Farmers estimated the quantity (kg/cow/day) of each item fed throughout the year. An 173 inventory of the feed offered to cattle was developed for each cow throughout the year. The 174 research team included an individual capable of identifying the various feed items in the event 175 that farmers were unable to identify the feed item and/or provided a local language name.

\subsection{FMD outbreak}

177 The surveyed villages experienced an outbreak of FMD with the earliest cases being 178 identified in July (early rainy season). No indigenous (non-descript) cows ( $\mathrm{n}=15)$ kept by 179 sampled households were infected. Participation in the government subsidized vaccination 180 program prior to the FMD outbreak was variable between households. Following the first 181 confirmed cases a widespread vaccination program was implemented at which time all 182 sampled households had their cloven hooved livestock (cattle, sheep and goats) vaccinated. 183 Table 1 outlines the number of infected cows and prevalence of FMD amongst the sampled 184 households.

185 The feed intake of infected cows would be expected to reduce during periods of FMD 186 infection due to lesions in the mouth and on the tongue. Reduced feed intakes would reduce 187 GHG emission. The extent of intake reductions could not be determined as farmers were unable to estimate the difference in feeding strategies during periods of infection. 
Table 1: The number of crossbred Jersey cows infected with Foot and Mouth Disease (FMD) within the sampled households of Puri and Khurda districts in Odisha, India. The total number of crossbred Jersey cows sampled and the prevalance of FMD within the sampled population is also provided (mean \pm SD).

\begin{tabular}{llllll}
\hline District & Village & $\begin{array}{l}\text { Households } \\
\text { sampled }\end{array}$ & $\begin{array}{l}\text { Cattle } \\
\text { sampled }\end{array}$ & $\begin{array}{l}\text { Cattle } \\
\text { infected }\end{array}$ & Prevalence (\%) \\
\hline Puri & Kalapanchana & 25 & 17 & 1 & 5.88 \\
& Madhi Brahmapur & 6 & 2 & 1 & 50 \\
\multirow{4}{*}{ Khurda } & Kendubilwa & 23 & 44 & 16 & 36.36 \\
& Nana Kara & 17 & 30 & 12 & 40 \\
& Raula & 29 & 31 & 10 & 32.26 \\
& Saheb Nagar & 2 & 1 & 0 & 0 \\
& Uparashai & 13 & 29 & 7 & 24.14 \\
& & 115 & 154 & 47 & $30.52 \pm 18.24$ \\
\hline
\end{tabular}

204 The lactation curve of the sampled uninfected cows ( $=52)$ and FMD infected cows ( $=36)$

205 were used to determine:

- average milk production throughout the year

- quantity of milk lost during an FMD outbreak,

- and the length of infection (as indicated by a restoration in milk yield). 
210 The quantity of milk lost during infection does not include the losses associated with the 211 cows which died $(n=3)$ or were sold $(n=4)$. Thus, the overall loss in productivity could be 212 much greater than currently being examined if these cows were to be included. Similarly, 213 cows which did not recover to pre-infection levels $(\mathrm{n}=5)$, stopped lactating completely $(\mathrm{n}=$ $2142)$ died $(n=3)$ or were sold prior to recovery $(n=4)$ were excluded from length of infection calculations.

216 The average milk production of uninfected crossbred Jersey cows was $1237 \mathrm{~kg} / \mathrm{cow} / \mathrm{lactation}$ $217(\mathrm{n}=52, \mathrm{SD}=620.81)$. The average lactation length was 250 days. FMD infected crossbred 218 Jersey cows yielded on average $1199 \mathrm{~kg} / \mathrm{cow} / \mathrm{lactation}(\mathrm{n}=36, \mathrm{SD}=555.27)$. Indeed, this 219 appears as only a minor reduction in yield. However, the FMD infected cows were above 220 average yielding animals. Immediately prior to infection average yield was $6.1 \mathrm{~kg} / \mathrm{cow} / \mathrm{day}$ 221 (SD = 1.99). The FMD affected cows were assumed to reflect productivity under conditions 222 in which no FMD control had been in place.

223 A portion of the decline in milk yield during FMD infection can be attributed to normal 224 declines expected as the lactation progresses (Moran, 2005). The normal rate of decline was 225 calculated from the lactation curves of the sampled healthy Jersey crossbred cows present for 226 the entire 12-months preceding the interview $(n=52)$. The average normal rate of decline in 227 milk yield was found to be $0.8 \mathrm{~kg} /$ month $(12.7 \%$ per month, $\mathrm{SD}=0.50)$. The quantity of milk 228 loss attributed to FMD infection was reduced by the monthly normal rate of milk decline for 229 the duration of the infection.

230 The duration of reduced milk yield due to FMD was 1.71 months ( $\mathrm{SD}=0.76)$. As the 231 majority of infections were noted in the rainy season (June - September) it was assumed milk 232 yield would be reduced for the months of June and July. Therefore, the entire month of June 233 (30 days) and a portion of July (71\% or 22 days) would experience reduced milk yields.

234 Based on these assumptions, the total quantity of milk lost during an outbreak of FMD was 235 found to be $183 \mathrm{~kg}$ /cow/outbreak. Therefore, control of FMD will increase the productivity of 236 cows from $1199 \mathrm{~kg} / \mathrm{cow} / \mathrm{lactation}$ to $1382 \mathrm{~kg} / \mathrm{cow} /$ lactation. The parameters and calculations 237 required to determine the level of improvement in milk yield following the control of FMD is 238 provided in Table 2. 
240 Table 2: The parameters and calculations required to determine the level improvement in milk yield following

241 the control of Foot and Mouth Disease (FMD) in Odisha, India.

\begin{tabular}{|c|c|c|c|c|}
\hline Parameter & Calculation method & Value & $\begin{array}{l}\text { Standard } \\
\text { deviation }\end{array}$ & Unit \\
\hline Uninfected cow & Field data $(\mathrm{n}=52)$ & 1237 & 620.81 & $\mathrm{~kg} / \mathrm{cow} /$ lactation \\
\hline $\begin{array}{l}\text { Normal rate of } \\
\text { decline }\end{array}$ & Field data $(\mathrm{n}=52)$ & 0.8 & 0.50 & $\mathrm{~kg} / \mathrm{cow} / \mathrm{day}$ \\
\hline FMD infected cow & Field data $(\mathrm{n}=36)$ & 1199 & 555.27 & $\mathrm{~kg} / \mathrm{cow} / \mathrm{lactation}$ \\
\hline $\begin{array}{l}\text { Production lost } \\
\text { during infection }\end{array}$ & Field data $(n=29)$ & 4.89 & 2.55 & $\mathrm{~kg} / \mathrm{cow} /$ day \\
\hline $\begin{array}{l}\text { Duration of reduced } \\
\text { yield }\end{array}$ & Field data $(n=22)$ & 1.71 & 0.76 & Months \\
\hline $\begin{array}{l}\text { Duration of reduced } \\
\text { yield }\end{array}$ & Field data $(\mathrm{n}=22)$ & 52 & 0.76 & Days \\
\hline $\begin{array}{l}\text { Normal quantity } \\
\text { lost over } 1.71 \\
\text { months }\end{array}$ & $\begin{array}{l}\text { Duration of reduced yield (months) } x \\
\text { Normal rate of decline }\end{array}$ & 1.37 & - & $\mathrm{kg} / \mathrm{cow} /$ day \\
\hline $\begin{array}{l}\text { Loss due to FMD } \\
\text { infection }\end{array}$ & $\begin{array}{l}\text { Production lost during infection - } \\
\text { Normal quantity lost over } 1.71 \text { months }\end{array}$ & 3.52 & - & $\mathrm{kg} / \mathrm{cow} /$ day \\
\hline $\begin{array}{l}\text { Total quantity lost } \\
\text { during a FMD } \\
\text { outbreak }\end{array}$ & $\begin{array}{l}\text { Loss due to FMD infection x Duration } \\
\text { of reduced yield (days) }\end{array}$ & 183 & - & $\mathrm{kg} / \mathrm{cow} /$ outbreak \\
\hline $\begin{array}{l}\text { Yield following } \\
\text { FMD control }\end{array}$ & $\begin{array}{l}\text { Total quantity lost during a FMD } \\
\text { outbreak + FMD infected cow }\end{array}$ & 1382 & - & $\mathrm{kg} / \mathrm{cow} /$ lactation \\
\hline
\end{tabular}

243 For comparability, it was assumed that the herd would consist of four adult crossbred Jersey

244 cows. Using the prevalence of FMD infection across the sampled villages (30.52\%) it was

245 assumed that only one lactating cow would be affected. However, such a scenario does not

246 reflect the highly contagious nature of FMD. A second scenario was considered assuming that

247 all four cows were infected. The parameters used to inform each scenario are provided in

248 Table 3. As high producing cows were found to be more susceptible to FMD infectionit was

249 assumed that the FMD control would increase production to $1382 \mathrm{~kg} / \mathrm{cow} / \mathrm{lactation}$.

250 The installation of smallscale anaerobic digesters would not have any direct influence on the

251 productivity of cows. It was assumed that the productivity of the cows would remain the same

252 as outlined in Table 3. 
Table 3: The effect of Foot and Mouth Disease (FMD) on milk yields as considered in two scenarios representing different rates of infection in a herd of four cows in Odisha, India.

Scenario 1 = one adult cow was assumed to be infected with FMD as determined from prevalence of the disease in the sampled sites; Scenario 2 = all adult cows were assumed infected with FMD as expected by the highly contagious nature of FMD.

\subsection{Calculating total GHG emissions}

A detailed account of emission calculation is provided in York (2017). A summary of the methods employed is provided.

\subsubsection{Enteric methane emissions}

Methane emissions were based on the quantity of feed offered to animals relevant to the dairy sector. Feeding strategies were provided by farmers. The nutritional value of each feed item was determined from Feedipedia (2012). Average emission estimates were derived on a per head basis with the use of IPCC (2006a) protocols. However, the Indian specific Methane

273 Conversion Factor (MCF) (Singhal et al., 2005; Jha et al., 2011) was used.

274 Adult cow emissions were scaled to reflect the different productive states over a 12-month

275 period. Lactation length was determined from field data $(n=78)$ and found to be an average of 276250 days $(\mathrm{SD}=78.95)$ for Jersey crossbred cows. Scaling was achieved by dividing the 277 annual Methane Emission Factor (MEF) by the number of days per year (i.e. 365) to obtain a 278 daily MEF for lactating and non-lactating periods. The daily MEFs were then multiplied by 279 the average length of the lactation (250 days) and dry periods (115 days). The figures were 280 added to provide an annual MEF. Only emissions of crossbred Jersey cows were considered 281 as no indigenous (non-descript) cows were affected by FMD. The MEF used to inform the 
analysis for each category of Jersey crossbred relevant to the dairy sector is provided in Table 2834.

\subsubsection{Manure methane emissions}

285 Manure methane emissions were calculated based on IPCC (2006a) protocols. However, the 286 Indian specific value for ash (17\%) (Gaur et al., 1984) was used. Volatile Solid (VS) content 287 was calculated from feed offered to the animal with the use of IPCC (2006a) protocols. To calculate the Manure Methane Emission Factor (MMEF), it was assumed all manure was either made into dung cakes or placed into an anaerobic digester. The IPCC (2006a) formula was adapted by removing the weighting factor (Equation 1)). The manure emissions from adult cows were scaled (as outlined in Section 2.5.1) to account got lactation and non-

292 lactation periods.

Equation 1: The adapted IPCC (2006a) equation used to determine the total quantity of methane emitted per cow as determined from feed offered to sampled cows in Odisha, India.

$$
\text { Manure Methane Emission Factor }=[V S * 365] *\left[B_{o} * 0.67 \mathrm{~kg} / \mathrm{m}^{3} * \frac{M M C F}{100}\right]
$$

Manure Methane Emission Factor $=$ annual $\mathrm{CH}_{4}$ emission, $\mathrm{kg} \mathrm{CH}_{4} /$ cow per year $\mathrm{VS}=$ daily volatile solid content of Indian dairy cow manure, $\mathrm{kg}$ per day 365 = basis for calculating annual VS production, days per year $\mathrm{B}_{0}=$ maximum methane producing capacity for manure produced by an Indian dairy

Dung cake making was selected as the manure management strategy for comparison as it is the dominant manure management system in the sampled sites (Government of India, 2011a). cow, $0.13 \mathrm{~m}^{3} \mathrm{CH}_{4}$ per $\mathrm{kg}$ of VS excreted The Manure Methane Conversion Factor (MMCF) for dung cake making was assumed to be $10 \%$ (IPCC, 2006a). The MMCF is used to indicate the extent to which maximum methane producing capacity $\left(\mathrm{B}_{\mathrm{o}}\right)$ is achieved under a specific manure management system (IPCC, 2006a). As outlined in Eq. (1), $\mathrm{B}_{\mathrm{o}}$ is assumed to be $0.13 \mathrm{~m}^{3} \mathrm{CH}_{4}$ per $\mathrm{kg}$ of VS excreted.

311 The MMCF for the anaerobic digester was determined from the rate of leakage

312 (Khoiyangbam et al., 2004; Khoiyangbam, 2008; Bruun et al., 2014) based on the works of 
313 Khoiyangbam (2008) and Khoiyangbam et al. (2004). Ideally, leakage would have been

314 measured directly. However, the logistics and resources associated with measuring leakage

315 from a large number of anaerobic digesters was beyond the scope of this investigation. As

316 such, it was assumed that the leakage measured by Khoiyangbam (2008) and Khoiyangbam et

317 al. (2004) (and also used by Bruun et al. (2014) provided a sufficiently robust estimate.

318 The MMCF offered by Bruun et al. (2014) (i.e. 17\%) could not be used as the author assumed

319 that $0.4 \mathrm{~m} 3$ of biogas is produced per $\mathrm{m}^{3}$ of digester size. Based on this assumption, to

320 calculate methane leakage as a percentage of total production in a $2 \mathrm{~m}^{3}$ system, $0.8 \mathrm{~m}^{3}$ of

321 biogas is produced per day. As biogas is $60 \%$ methane (Khoiyangbam et al., 2004;

322 Khoiyangbam, 2008; Bruun et al., 2014) a total of $0.48 \mathrm{~m}^{3}$ of methane is produced per day.

323 Following a conversion to kilograms via a conversion factor of 0.67 (IPCC, 2006a) and

324 extrapolation across an entire year (365 days), annual methane production would be 117.38

$325 \mathrm{~kg} \mathrm{CH}_{4} /$ year. As such, the measured leakage of $53.2 \mathrm{~kg} \mathrm{CH}_{4} /$ year would represent $45.32 \%$ of

326 total methane produced.

327 A simplified approach was developed to represent the measured leakage as a percentage of

328 total methane production (i.e. MMCF). It was assumed that that the system under

329 investigation $\left(2 \mathrm{~m}^{3}\right)$ was achieving maximum methane production. The maximum methane

330 producing ability of cow manure $\left(0.13 \mathrm{~m}^{3} \mathrm{CH}_{4} / \mathrm{kg} \mathrm{VS}\right)$ (IPCC, 2006a) and VS excretion rate

331 of Indian cows (2.6 kg VS/head/day) (IPCC, 2006a) were used. It was assumed four cows

332 were required to produce sufficient manure to ensure maximum working capacity. A total of

$3331.35 \mathrm{~m}^{3} \mathrm{CH}_{4} /$ day was calculated to be produced. Yearly methane production was calculated to

334 be $493.48 \mathrm{~m}^{3}$. This value was converted to kilograms of a methane via a conversion factor of

3350.67 (IPCC, 2006a). Total production was found to be $330.63 \mathrm{~kg} \mathrm{CH} 4 /$ year. Therefore,

336 leakage of $53.2 \mathrm{~kg} \mathrm{CH}_{4} /$ year represents $16.09 \%$ of the total amount possible.

337 This method of converting digester leakage estimates to a MMCF was then applied to the 338 leakage estimate offered by Khoiyangbam et al., (2004). Khoiyangbam et al., (2004) found 339 methane leakage from a $2 \mathrm{~m}^{3}$ Deenbandhu system to be $46.4 \mathrm{~kg} \mathrm{CH} /$ year. Only leakage from

340 the fixed dome Deenbandhu system was considered as this is the most common type of

341 digester installed in India (Government of India, 2002). The calculation was repeated to 342 convert the value provided by Khoiyangbam (2008) to a MMCF. An average of the newly

343 calculated MMCFs (i.e. 14.0\% (Khoiyangbam et al., 2004) and 15.2\% (Khoiyangbam, 2008))

344 was calculated. The average MMCF used in this analysis for anaerobic digestion was $14.6 \%$. 
$345 \quad \mathrm{~N}_{2} \mathrm{O}$ emissions from manure were not included in this investigation as the manure

346 management systems under investigation (i.e. anaerobic digestion, dung cake making) are not

347 expected to emit $\mathrm{N}_{2} \mathrm{O}$ (IPCC, 2006a). Additional methane emission is also expected for any

348 manure that is left stacked in piles prior to dung cake making. Thse sources were not

349 included as they are expected to be relatively minor (Government of India, 2012a), Table 4

350 provides the MMEF for each category of Jersey crossbred cattle relevant to the dairy sector if

351 the manure is managed as dung cakes or anaerobic digestion.

\subsection{Calculating methane emission intensity}

353 Emission intensity is a measure of GHG emission in terms of productive output. As the

354 slaughter of cattle is illegal in Odisha (Government of Odisha, 1961) it was assumed that the 355 total quantity of GHG emitted can be assigned to milk production.

356 To ensure comparability between anaerobic digestion and FMD control, it was necessary to

357 assume that households kept four adult cows. This is the number of adult cows required to 358 produce sufficient manure for maximum anaerobic digester functionality (assuming a system 359 size of $2 \mathrm{~m}^{3}$ ). However, the calculation of emission intensity requires inclusion of emissions 360 from non-productive components of the herd. The total number of cattle sampled was used to 361 indicate the number of non-productive cattle kept per adult cow. For example, for every adult cow sampled, 0.27 young heifers were sampled.

363 Due to the inclusion of non-productive cattle in the herd, more manure will be produced than 364 can be utilised by a $2 \mathrm{~m}^{3}$ Deenbandhu anaerobic digester. It was assumed excess manure 365 (from non-productive cattle) will be managed as dung cakes. All manure produced from the 366 four adult cows was assumed to be available for use in the anaerobic digester or made into 367 dung cakes. The interval of use (i.e. time taken to make into dung cakes, or load into the 368 digester) was not considered as emissions were not expected from these sources (Government of India, 2012a). The herd size and structure is shown in Table 4.

370 Emission factors were scaled to herd structure (Table 4). Scaling was necessary as emission 371 factors are reported on a per head basis. Scaling was achieved by multiplying the number of 372 animals kept per four adult cows via the MEF, MMEF under dung cake making, and MMEF 373 under anaerobic digestion. For example, the MEF of male calves (6.33 $\mathrm{kg} \mathrm{CH}_{4} /$ year) was 374 multiplied by the number of male calves (i.e. 0.41) kept. 
375 Total methane production was converted to $\mathrm{CO}_{2}$ equivalents by multiplication of the emission 376 estimate and the GWP of methane at a 100 year timeframe (IPCC, 2013). The GWP of $\mathrm{CH}_{4}$

377 was assumed to be 25 (IPCC, 2007). The methane emission intensity was calculated by

378 dividing the $\mathrm{CO}_{2}$ equivalents by the total quantity of milk produced from the herd under the

379 different manure management and disease scenarios.

380 Table 4: The average Methane Emission Factors (MEF) and Manure Methane Emission Factors (MMEF)

381 calculated from the diets of cattle subject to smallholder conditions in Odisha, India. Manure Methane Emission

382 Factors (MMEF) are provided for dung cake making and anaerobic digestion, Methane Emission Factors (MEF)

383 and Manure Methane Emission Factors (MMEF) are provided in kg of methane/animal per year. The herd

384 structure assumed for the comparison of GHG emission mitigation policies is also provided

\begin{tabular}{|c|c|c|c|c|c|c|}
\hline & $\begin{array}{l}\text { Sample } \\
\text { size (n) }\end{array}$ & MEF & $\mathrm{MMEF}_{\text {Cake }}$ & $\mathrm{MMEF}_{\text {Digester }}$ & Herd structure calculation & $\begin{array}{l}\text { Herd } \\
\text { structure }\end{array}$ \\
\hline Cow $^{\mathrm{a}}$ & 116 & 43.91 & 7.74 & 10.88 & - & 4 \\
\hline Male calf & 12 & 6.33 & 0.85 & - & (Male calf $\div$ Cow $) \times 4$ & 0.41 \\
\hline Female calf & 14 & 15.89 & 2.24 & - & $($ Female calf $\div) * 4$ & 0.48 \\
\hline $\begin{array}{l}\text { Young } \\
\text { heifers }\end{array}$ & 31 & 21.74 & 2.99 & - & (Young heifer $\div$ Cow) $\mathrm{x} 4$ & 1.07 \\
\hline Older heifers & 22 & 25.02 & 3.45 & - & (Older heifer $\div$ Cow $) \times 4$ & 0.76 \\
\hline Young males & 1 & 6.35 & 0.82 & - & (Young male $\div$ Cow) $\mathrm{x} 4$ & 0.03 \\
\hline $\begin{array}{l}\text { Total herd } \\
\text { size }\end{array}$ & - & - & - & - & & 6.76 \\
\hline
\end{tabular}

386 Male calf $=<1$ year old; Female calf $=<1$ year old; Young heifer $=1$ year $-<2.5$ years; Older heifers $=>2.5$

387 years (not calved); Young males $=1$ year $-<2.5$ years.

$388 \mathrm{MEF}=$ Estimate based on the Methane Conversion Factor (MCF) provided by (Singhal et al., 2005; Jha et al., 389 2011)

$390 \mathrm{MMEF}_{\mathrm{Cake}}=$ Estimate based on the Indian specific value for ash (17\%) (Gaur et al., 1984) assuming MCF for 391 dung cake making is $10 \%$ (IPCC, 2006a).

$392 \mathrm{MMEF}_{\text {Digester }}=$ Estimate based on the Indian specific value for ash (17\%) (Gaur et al., 1984) assuming MCF for 393 anaerobic digestion is $14.6 \%$.

394 *Indicates that the manure will be made into dung cakes and assigned the $\mathrm{MMEF}_{\text {Cake. }}$

395 a The estimates of methane emission have been scaled to account for a lactation period of 250 days and dry 396 period of 115 days. 


\subsection{Herd emission}

399 Table 5 provides the contribution to emissions made by each category of Jersey crossbred 400 within the herd. Table 5 indicates that enteric emissions are the most important source of 401 emissions. Manure methane emission of adult cows represents $17.6 \%$ and $24.8 \%$ of enteric emissions when manure is managed as dung cakes and anaerobic digestion, respectively.

Table 5: The enteric methane and manure methane emissions calculated from the diets of cattle subject to smallholder conditions in Odisha, India. Manure is managed as dung cakes or anerobic digestion.

\begin{tabular}{|c|c|c|c|c|}
\hline & \multirow{3}{*}{\multicolumn{3}{|c|}{$\begin{array}{l}\text { Scaled contribution to emission intensity (kg } \\
\mathrm{CH}_{4} / \text { year) }\end{array}$}} & 405 \\
\hline & & & & 406 \\
\hline & & & & 407 \\
\hline & Enteric & Manure emission & Manure emi & 408 \\
\hline & emission $^{\mathrm{a}}$ & - Dung cakes ${ }^{\mathrm{b}}$ & - Digester ${ }^{\mathrm{c}}$ & 409 \\
\hline Cow & 175.64 & 30.96 & 43.52 & 411 \\
\hline Male calf & 2.62 & 0.35 & 0.35 & 412 \\
\hline Female calf & 7.67 & 1.08 & 1.08 & 413 \\
\hline Young heifers & 23.24 & 3.20 & 3.2 & 414 \\
\hline Older heifers & 18.98 & 2.62 & 2.62 & 15 \\
\hline Young males & 0.22 & 0.03 & 0.03 & 417 \\
\hline Total & 228.37 & 38.23 & 53.75 & 418 \\
\hline $\mathrm{CO}_{2}$ eq $(\mathrm{kg} \mathrm{CO} 2$ eq/year) & 5709.23 & 955.87 & 1343.85 & 419 \\
\hline
\end{tabular}

Male calf $=<1$ year old; Female calf $=<1$ year old; Young heifer $=1$ year $-<2.5$ years; Older heifers $=>2.5$ years (not calved); Young males $=1$ year $-<2.5$ years.

423 a Estimate based on the Methane Conversion Factor (MCF) provided by Jha et al., (2011) and Singhal et al., 424 (2005)

$425{ }^{\mathrm{b}}$ Estimate based on the Indian specific value for ash (17\%) (Gaur et al., 1984) assuming MCF for dung cake 426 making is $10 \%$ (IPCC, 2006a).

$427{ }^{\mathrm{c}}$ Estimate based on the Indian specific value for ash (17\%) (Gaur et al., 1984) assuming MCF for anaerobic 428 digestion is $14.64 \%$.

\subsection{Emission intensity and mitigation}

430 Table 26 provides the methane emission intensity of milk production in Odisha India. Control

431 of FMD reduces the methane emission intensity. However, the extent of reduction is

432 dependent on the scenario considered. Scenario 1 (only one adult cow infected) results in a 
433 minor reduction in emission intensity (3.68\%) whilst Scenario 2 (all adults infected) results in

434 a more significant reduction of $12.95 \%$. The installation of a smallscale anaerobic digester

435 will increase GHG emission intensity by between $4.41-5.01 \%$.

436

437

Table 2: The emission intensity of milk production in Odisha, India under different emission mitigation

438 strategies. Mitigation strategies include Foot and Mouth Disease (FMD) control and installation of smallscale

439 anaerobic digesters.

\begin{tabular}{|c|c|c|c|}
\hline \multicolumn{2}{|l|}{ Scenario 1} & \multirow{2}{*}{$\begin{array}{l}\text { Value } \\
1.36\end{array}$} & \multirow{2}{*}{$\begin{array}{l}\text { Unit } \\
\mathrm{kg} \mathrm{CO} 2 \mathrm{eq} / \mathrm{kg} \mathrm{mill}\end{array}$} \\
\hline No FMD control & Manure managed as dung cakes & & \\
\hline \multirow{3}{*}{ FMD controlled } & Manure managed in anaerobic digester & 1.44 & $\mathrm{~kg} \mathrm{CO} 2 \mathrm{eq} / \mathrm{kg}$ milk \\
\hline & Manure managed as dung cakes & 1.31 & $\mathrm{~kg} \mathrm{CO} 2 \mathrm{eq} / \mathrm{kg}$ milk \\
\hline & Manure managed in anaerobic digester & 1.39 & $\mathrm{~kg} \mathrm{CO} 2 \mathrm{eq} / \mathrm{kg}$ milk \\
\hline \multicolumn{2}{|c|}{$\begin{array}{l}\text { Change in emission intensity following anaerobic digester } \\
\text { installation }\end{array}$} & +5.50 & $\%$ \\
\hline \multicolumn{2}{|c|}{ Change in emission intensity following FMD control } & -3.56 & $\%$ \\
\hline \multicolumn{4}{|l|}{ Scenario 2} \\
\hline \multirow[t]{2}{*}{ No FMD control } & Manure managed as dung cakes & 1.39 & $\mathrm{~kg} \mathrm{CO} 2 \mathrm{eq} / \mathrm{kg}$ milk \\
\hline & Manure managed in anaerobic digester & 1.47 & $\mathrm{~kg} \mathrm{CO} 2 \mathrm{eq} / \mathrm{kg}$ milk \\
\hline \multirow[t]{2}{*}{ FMD controlled } & Manure managed as dung cakes & 1.21 & $\mathrm{~kg} \mathrm{CO} 2 \mathrm{eq} / \mathrm{kg}$ milk \\
\hline & Manure managed in anaerobic digester & 1.28 & $\mathrm{~kg} \mathrm{CO} 2 \mathrm{eq} / \mathrm{kg}$ milk \\
\hline \multicolumn{2}{|c|}{$\begin{array}{l}\text { Change in emission intensity following anaerobic digester } \\
\text { installation }\end{array}$} & +5.50 & $\%$ \\
\hline \multicolumn{2}{|c|}{ Change in emission intensity following FMD control } & -13.12 & $\%$ \\
\hline
\end{tabular}

Scenario 1 = one adult cow was assumed to be infected with FMD as determined from prevalence of the disease

441 in the sampled sites; Scenario 2 = all adult cows were assumed infected with FMD as expected by the highly

442 contagious nature of FMD. 
Table 6: The emission intensity of milk production in Odisha, India under different emission mitigation strategies. Mitigation strategies include Foot and Mouth Disease (FMD) control and installation of smallscale anaerobic digesters.

\begin{tabular}{|c|c|c|c|}
\hline \multicolumn{2}{|l|}{ Scenario 1} & Value & Unit \\
\hline \multirow[t]{2}{*}{ No FMD control } & Manure managed as dung cakes & 1.36 & $\mathrm{~kg} \mathrm{CO} 2 \mathrm{eq} / \mathrm{kg}$ milk \\
\hline & Manure managed in anaerobic digester & 1.42 & $\mathrm{~kg} \mathrm{CO} 2 \mathrm{eq} / \mathrm{kg}$ milk \\
\hline \multirow[t]{2}{*}{ FMD controlled } & Manure managed as dung cakes & 1.31 & $\mathrm{~kg} \mathrm{CO} 2 \mathrm{eq} / \mathrm{kg}$ milk \\
\hline & Manure managed in anaerobic digester & 1.37 & $\mathrm{~kg} \mathrm{CO} 2 \mathrm{eq} / \mathrm{kg}$ milk \\
\hline \multicolumn{2}{|c|}{ Change in emission intensity following anaerobic digester installation } & +4.41 & $\%$ \\
\hline \multicolumn{2}{|c|}{ Change in emission intensity following FMD control } & -3.68 & $\%$ \\
\hline \multicolumn{2}{|l|}{ Scenario 2} & Value & Unit \\
\hline \multirow[t]{2}{*}{ No FMD control } & Manure managed as dung cakes & 1.39 & $\mathrm{~kg} \mathrm{CO} \mathrm{Cq}_{2} \mathrm{eqg}$ milk \\
\hline & Manure managed in anaerobic digester & 1.46 & $\mathrm{~kg} \mathrm{CO}{ }_{2} \mathrm{eq} / \mathrm{kg}$ milk \\
\hline \multirow[t]{2}{*}{ FMD controlled } & Manure managed as dung cakes & 1.21 & $\mathrm{~kg} \mathrm{CO}{ }_{2} \mathrm{eq} / \mathrm{kg}$ milk \\
\hline & Manure managed in anaerobic digester & 1.26 & $\mathrm{~kg} \mathrm{CO}{ }_{2} \mathrm{eq} / \mathrm{kg}$ milk \\
\hline \multicolumn{2}{|c|}{ Change in emission intensity following anaerobic digester installation } & +5.01 & $\%$ \\
\hline \multicolumn{2}{|c|}{ Change in emission intensity following FMD control } & -12.95 & $\%$ \\
\hline
\end{tabular}

Scenario 1 = one adult cow was assumed to be infected with FMD as determined from the prevalence of the disease in the sampled sites; Scenario $2=$ all adult cows were assumed infected with FMD as expected by the highly contagious nature of FMD.

\section{Discussion}

\subsection{Emission intensity}

456 The development of robust measures of emission intensity is a necessary first step from which 457 mitigation can be considered. The calculated emission intensities (i.e. 1.26-1.46 $\mathrm{kg} \mathrm{CO}_{2}$ eq/kg milk) are higher than existing methane estimates for Indian crossbred dairy cows (0.53$0.70 \mathrm{~kg} \mathrm{CO} 2 \mathrm{eq} / \mathrm{kg}$ of milk (Swamy and Bhattacharya, 2006; Jha et al., 2011). However, the comparability is limited due to the incompleteness of previous research (as discussed in

461 Section 1). Additionally, the cows included in this investigation were Jersey crossbred cows.

462 It is unlikely that this cow type is comparable to 'crossbred' cows (most likely Holstein 463 Friesian crossbreds) considered by previous authors (see Swamy and Bhattacharya, 2006; Jha 464 et al., 2011).

\subsection{Mitigation}

466 The results clearly demonstrate the efficacy of different policy based interventions in 467 altering the methane emission intensity of milk production. The control of FMD was found to 
reduce emission intensity by $3.68-12.95 \%$ whilst the installation of a smallscale anaerobic

469 digester was found to increase emission intensity by $4.41-5.01 \%$. The ineffectiveness of the anaerobic digester is due to the comparatively climate change-benign nature of traditional

471 Indian manure management practices (i.e. making dung cakes). If manure was managed in its 472 liquid form, as is the case in intensive production systems of the global north, the installation

473 of anaerobic digesters would be a more effective mitigation strategy than identified by this

474 investigation. Thus, smallscale anaerobic digesters lack contextual relevance and are ill-

475 suited to achieving emission reductions within the Indian smallholder dairy sector.

476 Conversely, the control of FMD resulted in a reduction in emission intensity. Indeed, it is 477 unsurprising that attempts to improve productivity (via improved health) reduces emission 478 intensity. Yet, Indian livestock policy is silent on the mitigation co-benefit that can result 479 from improved animal health. The results highlight the need for policymakers to explicitly 480 recognise the importance of the mitigation co-benefit associated with FMD control and 481 animal health policies more generally.

482 A number of authors discuss the potential usefulness of improved health as a means of 483 reducing emission intensity (see Gerber et al., 2013; Hristov et al., 2013). However, northern 484 production systems have primarily been the focus of studies. For example, using a LCA in 485 Spain, Hospido and Sonesson (2005) found control of mastitis to have a positive effect on 486 GHG emissions. Similarly, in the United Kingdom Stott et al. (2010) found a mastitis control 487 program could achieve a 1.5-2\% improvement in productivity which reduced UK dairy sector 488 emissions by $8 \%\left(0.4 \mathrm{Mt} \mathrm{CO}_{2} \mathrm{eq}\right)$. Such results are largely unsurprising as the core outcome 489 of improved animal health is improved productive efficiency. Studies highlight the 490 importance of enhanced productivity in achieving dairy sector emission intensity reductions 491 (eg Beukes et al., 2010; Bell et al., 2013). Thus, it is the current low levels of productivity which make the smallholder sector particularly responsive to such interventions.

493 Biogas leakage from anaerobic digesters has been an area of increasing research interest (e.g. 494 Khoiyangbam et al., 2004; Khoiyangbam, 2008; Bruun et al., 2014). However, previous studies have been unable to estimate the importance of this leakage to increasing dairy sector GHG emissions. Rather, studies have focused on the effect of anaerobic digester installation 497 on total emissions (Bhattacharya et al., 1997; Pathak et al., 2009). In doing so, the authors 498 have ignored important gaps in knowledge with regard to baseline estimates of digester 499 leakage. By not recognising the importance of digester leakage (compared to existing manure 
management strategies) such studies have overestimated the likely reduction in GHG

501 emission that can be achieved by digester installation.

502 Additionally, as biogas leakage occurs prior to combustion this source of emission must be

503 assigned to the dairy sector (IPCC, 2006b). AS a result, net emissions from the energy sector

504 are reduced (via a substitution of burning fossil fuels and/or firewood) to the detriment of

505 dairy sector emissions. This is concerning as there are currently no interventions available

506 that can directly (and easily) reduce dairy sector emissions. Yet, there are alternate mitigation

507 options available to the energy sector (eg solar). Thus, it may be advantageous to utilise

508 methods within the energy sector that do not transfer emissions into the dairy sector due to the

509 difficulties in mitigating dairy sector emissions.

510 Alternatively, it may be necessary to redesign the anaerobic digesters to reduce the risk of

511 leakage. This is advantageous as emissions could be reduced to zero as noted in northern

512 large scale anaerobic digesters (eg Kaparaju and Rintala, 2011). Redesigning the anaerobic

513 digester will also ensure that the significant benefits accrued to the household following

514 installation are retained.

515 There are significant gaps in knowledge regarding methane emissions from dung cakes and

516 the extent to which leakage is a problem for anaerobic digesters. Thus, there is an inherent

517 level of uncertainty arising from such gaps in knowledge. Specifically, this investigation

518 assumes that the maximum methane emission is achieved during anaerobic digestion.

519 Although the assumption is logical as the objective of anaerobic digestion is to provide

520 conditions conducive to methane production, it is possible that maximum methane emission is

521 not achieved. For example, manure managed in a lagoon system has a MCF of $78 \%$ (at $21^{0} \mathrm{C}$ )

522 (IPCC, 2006a). Therefore, the current sudy may underestimate the importance of the leakage

523 measured by Khoiyangbam et al., (2004) and Khoiyangbam (2008). As such, future research

524 should explicitly consider leakage as a percentage of total methane produced during digestion.

525 Additionally, although the measures provided by Khoiyangbam et al., (2004) and

526 Khoiyangbam (2008) are average annual estimates, methane emission is temperature

527 dependent. Variability in the rate of leakage should also be considered.

528 Therefore, further research is urgently required in two key areas. Firstly, emissions arising

529 during dung cake making must be accurately measured to ensure that this method of manure

530 management is as climate-change-benign as authors assume it to be (USEPA, 1992; IPCC,

531 2006a; Government of India, 2010). Secondly, a thorough evaluation of biogas production 
532 potential and leakage (including direct measurement) must be undertaken to gain a better 533 understanding of the usefulness of smallscale anaerobic digesters in terms of GHG emission 534 reduction from the dairy sector. The outcomes of such research will inform future revision of 535 IPCC values.

536 The study is also limited by relatively simple calculations used to predict milk yield following 537 the control of FMD. Such calculations are likely subject to large uncertainty as suggested by 538 the milk yield standard deviations. As such, future research should include a sensitivity 539 analysis and statistical analysis to better understand the significance of FMD impacts on milk 540 yields. Nonetheless, this study is an important contribution to knowledge as it an important 541 proof of concept that demonstrates the importance of developing contextually relevant 542 mitigation strategies. By not adequately considering baseline emission scenarios, 543 policymakers risk the use of ill-suited interventions which will inevitably fail to deliver 544 desired outcomes.

545 Importantly, the study indicates that a reduction in overall population size is not required to 546 achieve a reduction in emission intensity. It is recommended policymakers further explore 547 productivity improving interventions (eg FMD control) to identify and exploit co-benefit 548 mitigation opportunities. However, within the socio-cultural context of India questions 549 remain as to whether emission intensity reductions will ever be large enough to precipitate a 550 decline in total emissions due to the unpalatability of a reduced national dairy herd and 551 increasing demand for milk products (Delgado et al., 1999; Pica-Ciamarra and Otte, 2009).

552 In conclusion, this study highlights the need for policymakers to take a multi-disciplinary 553 approach to emission mitigation by implementing a broad agenda considering a range of 554 sectors and their interactions. By installing smallscale anaerobic digesters, emissions are 555 moved from the energy sector into the dairy sector where they are inherently difficult to 556 mitigate. Improving animal health will reduce the emission intensity of milk production with 557 no immediate overall effect on net emissions. Where the impacts of an intervention appear 558 discrete and there is no movement of emissions to other sectors (such as with FMD control) it 559 should be pursued. However, where an interaction between sectors is noted, care must be 560 taken as to move emissions into a sector where they are difficult to mitigate (e.g. the dairy 561 sector) may limit the long-term usefulness of the strategy. Indeed, the movement of emissions 562 between sectors is a purely political exercise. Yet, a failure to recognise such political 563 manoeuvring will likely limit the cost-effectiveness of economy wide emission reduction. 
565 The authors would like to thank Dr. Soumya Pani and Dr. Niranjan Panda from the Orissa

566 University of Agriculture and Technology and the secretary of the Women's Federation,

567 Sabita Sethy, for their advice and support during field activities. The authors also thank the

568 participant farmers for their patience and willingness to aid the research. Funding was

569 provided by the Harriett Beard Travelling Scholarship from the University of Sydney which

570 had no influence on any aspect of the study. The research was conducted as approved by the

571 Ethical Clearance Board of the University of Reading, UK (reference number: APD - B141)

\section{References}

573 Adler, A.A., Doole, G.J., Romera, A.J., Beukes, P.C., 2013. Cost-effective mitigation of

574 greenhouse gas emissions from different dairy systems in the Waikato region of New

575 Zealand. J. Environ. Manage. 131, 33-43.

576 Bell, M.J., Eckard, R.J., Haile-Mariam, M., Pryce, J.E., 2013. The effect of changing cow

577 production and fitness traits on net income and greenhouse gas emissions from Australian

578 dairy systems. J. Dairy Sci. 96, 7918-7931.

579 Beukes, P.C., Gregorini, P., Romera, A.J., Levy, G., Waghorn, G.C., 2010. Improving

580 production efficiency as a strategy to mitigate greenhouse gas emissions on pastoral dairy

581 farms in New Zealand. Agr. Ecosyst. Environ. 136, 358-365.

582 Bhattacharya, S.C., Thomas, J.M., Abdul Salam, P., 1997. Greenhouse gas emissions and the

583 mitigation potential of using animal wastes in Asia. Energy 22, 1079-1085.

584 Bruun, S., Jensen, L.S., Khanh Vu, V.T., Sommer, S., 2014. Small-scale household biogas

585 digesters: An option for global warming mitigation or a potential climate bomb? Renew. Sust.

586 Energ. Rev. 33, 736-741.

587 Capper, J.L., Cady, R.A., Bauman, D.E., 2009. The environmental impact of dairy

588 production: 1944 compared with 2007. J. Anim. Sci. 87, 2160-2167.

589 Datta, T.N., Shrestha, Chokkalingam, G., 2015. Agricultural land and bovine population in

590 India: A critical review of agricultural census data. J. Rural Develop. 34, 167 - 186.

591 Delgado, C.L., Rosegrant, M.W., Steinfeld, H., Ehui, S.K., Courbois, C., 1999. Livestock to

592 2020: the next food revolution. International Food Policy Research Institute (IFPRI) 61.

593 Doole, G.J., 2014. Least-cost greenhouse gas mitigation on New Zealand dairy farms. Nutr.

594 Cycl. Agroecosys. 98, 235-251. 
595 FAO, 2010. Greenhouse Gas Emissions from the Dairy Sector: A Life Cycle Assessment.

596 Food and Agricultural Organization of the United Nations, Rome, Italy.

597 FAO, 2013. FAOSTAT Emissions Database. Food and Agricultural Organization of the

598 United Nations.

599 Feedipedia, 2012. Feedipedia - Animal feed resources information system. French National

600 Institute for Agricultural Research (INRA), Centre de coopération internationale en recherche

601 agronomique pour le développement (CIRAD), Association Française de Zootechnie(AFZ)

602 and Food and Agricultural Organization of the United Nations (FAO).

603 Foster, C., Audsley, E., Williams, A., Webster, S., Dewick, P., Green, K., 2007. The

604 environmental, social and economic impacts associated with liquid milk consumption in the

605 UK and its production: a review of literature and evidence. Department for Environment,

606 Food and Rural Affairs, London, UK.

607 Gaur, A.C., Neelakantan, S., Dargan, K.S., 1984. Organic manures. Indian Council of

608 Agricultural Research.

609 Gerber, P., Vellinga, T., Opio, C., Steinfeld, H., 2011. Productivity gains and greenhouse gas

610 emissions intensity in dairy systems. Livestock Science 139, 100-108.

611 Tackling climate change through livestock - A global assessment of emissions and mitigation

612 opportunities. In: Gerber, P.J., Steinfeld, H., Henderson, B., Mottet, A., Opio, C., Dijkman, J.,

613 Falcucci, A., Tempio, G. (Eds.), 2013. Food and Agriculture Organization of the United

614 Nations, Rome, Italy.

615 Government of India, 2002. Evaluation Study On National Project on Biogas Development.

616 Government of India, New Delhi.

617 Government of India, 2004. India's Initial National Communication to the United NAtions

618 Framework Convention on Climate Change. Government of India, New Delhi.

619 Government of India, 2010. India: Greenhouse Gas Emissions 2007. Government of India, 620 New Delhi.

621 Government of India, 2011a. Census 2011 - Percentage of Households to Total Households

622 by Amenities and Assets. Government of India, New Delhi.

623 Government of India, 2011b. Climate change \& 12th five year plan: report of sub-group on

624 climate change. Government of India, New Dehli.

625 Government of India, 2011c. Strategic Plan for New and Renewable Energy Sector for the

626 period 2011-2017. Ministry of New and Renewable Energy, New Delhi.

627 Government of India, 2012a. India: Second National Communication to the United NAtions

628 Framework Convention on Climate Change. Government of India, New Delhi. 
629 Government of India, 2012b. Report of the working group on animal husbandry and dairying 630 12th five year plan (2012 - 17). Government of India, New Delhi.

631 Government of India, 2013. National Livestock Policy 2013. Government of India, New

632 Delhi.

633 Government of India, 2014a. 19th Livestock Census - 2012 - All India report. Government of 634 India, New Delhi.

635 Government of India, 2014b. Basic Animal Husbandry and Fisheries Statistics. Government 636 of India, New Delhi.

637 Government of Odisha, 1961. The Orissa Prevention of Cow Slaughter Act, 1960.

638 Government of Odisha,, Bhubaneswar.

639 Herrero, M., Wirsenius, S., Henderson, B., Rigolot, C., Thornton, P., Havlík, P., de Boer, I., 640 Gerber, P.J., 2015. Livestock and the Environment: What Have We Learned in the Past

641 Decade? Annual Review of Environment and Resources 40, 177-202.

642 Hospido, A., Sonesson, U., 2005. The environmental impact of mastitis: a case study of dairy 643 herds. Sci. Total Environ. 343, 71-82.

644 Mitigation of greenhouse gas emissions in livestock production - A review of technical 645 options for non-CO2 emissions. In: Hristov, A.N., Oh, J., Lee, C., Meinen, R., Montes, F., 646 Ott, T., Firkins, J., Rotz, A., Dell, C., Adesogan, A., Yang, W., Tricarico, J., Kebreab, E., 647 Waghorn, G., Dijkstra, J., Oosting, S. (Eds.), 2013. Food and Agricultural Organization of the 648 United Nations, Rome, Italy.

649 IPCC, 2006a. Emissions from livestock and manure management. In: Eggleston, H.S.,

650 Buendia, L., Miwa, K., Ngara, T., Tanabe, K. (Eds.), 2006 IPCC Guidelines for National 651 Greenhouse Gas Inventories. Prepared by the National Greenhouse Gas Inventories 652 Programme, Intergovernmental Panel on Climate Change, Kamiyamaguchi, Japan, pp. 10.1165310.89.

654 IPCC, 2006b. N2O Emissions from managed soils and CO2 emissions from Lime and Urea 655 application. In: De Klein, C., Novoa, R.S.A., Ogle, S., Smith, K.A., Rochette, P., Wirth, T.C., 656 McConkey, B.G., Mosier, A., Rypdal, K. (Eds.), 2006 IPCC Guidelines for National 657 Greenhouse Gas Inventories. Prepared by the National Greenhouse Gas Inventories 658 Programme, International Panel on Climate Change, Kamiyamaguchi, Japan, pp. 11.11-11.54. 659 IPCC, 2007. Chapter 2: Changes in Atmospheric Constituents and in Radiative Forcing. In: 660 Solomon, S., Qin, D., Manning, M., Chen, Z., Marquis, M., Averyt, K.B., Tignor, M., Miller, 661 H.L. (Eds.), Climate Change 2007: The Physical Science Basis. Contribution of Working 
662 Group I to the Fourth Assessment Report of the Intergovernmental Panel on Climate Change.

663 Cambridge University Press, Cambridge, United Kingdom and New York, NY, USA.

664 IPCC, 2013. Annex III: Glossary. In: Stocker, T.F., Qin, D., Plattner, G.-K., Tignor, M.,

665 Allen, S.K., Boschung, J., Nauels, A., Xia, Y., Bex, V., Midgley, P.M. (Eds.), Climate

666 Change 2013: The Physical Science Basis Working Group I Contribution to the Fifth

667 Assessment Report of the Intergovernmental Panel on Climate Change. Cambridge University

668 Press, Cambridge, United Kingdom and New York, NY, USA, pp. 1447-1465.

669 International Farm Comparison Network, 2015. Calculator. International Farm Comparison

670 Network, Kiel, Germany.

671 Jha, A.K., Singh, K., Sharma, C., Singh, S.K., Gupta, P.K., 2011. Assessment of methane and

672 nitrous oxide emissions from livestock in India. Journal of Earth Science \& Climatic Change

$673 \quad 2,1-12$.

674 Kaparaju, P., Rintala, J., 2011. Mitigation of greenhouse gas emissions by adopting anaerobic

675 digestion technology on dairy, sow and pig farms in Finland. Renew. Energy 36, 31-41.

676 Khoiyangbam, R.S., Kumar, S., Jain, M.C., Gupta, N., Kumar, A., Kumar, V., 2004. Methane

677 emission from fixed dome biogas plants in hilly and plain regions of northern India.

678 Bioresource Technol. 95, 35-39.

679 Khoiyangbam, R.S., 2008. Greenhouse gases emission from energy production in

680 conventional biogas plants in India. Energy Sources, Part A 30, 689-697.

681 Knight-Jones, T.J.D., Rushton, J., 2013. The economic impacts of foot and mouth disease -

682 What are they, how big are they and where do they occur? Prev. Vet. Med. 112, 161-173.

683 Kristensen, T., Mogensen, L., Knudsen, M.T., Hermansen, J.E., 2011. Effect of production

684 system and farming strategy on greenhouse gas emissions from commercial dairy farms in a

685 life cycle approach. Livestock Science 140, 136-148.

686 Moran, J., 2005. Diet and milk production. In: Moran, J. (Ed.), Tropical dairy farming:

687 feeding management for small holder dairy farmers in the humid tropics. Landlinks Press,

688 Kyabram, Australia, pp. 159-170.

689 Opio, C., Gerber, P., Mottet, A., Falcucci, A., Tempio, G., MacLeod, M., Vellinga, T.,

690 Henderson, B., Steinfeld, H., 2013. Greenhouse gas emissions from ruminant supply chains:

691 A global life cycle assessment. Food and Agriculture Organization of the United Nations,

692 Rome, Itay.

693 Pathak, H., Jain, N., Bhatia, A., Mohanty, S., Gupta, N., 2009. Global warming mitigation

694 potential of biogas plants in India. Environmental Monitoring and Assessment 157, 407-418. 
695 Patra, A.K., 2012. Estimation of methane and nitrous oxide emissions from Indian livestock.

696 J. Environ. Monitor. 14, 2673-2268.

697 Pica-Ciamarra, U., Otte, J., 2009. The 'Livestock Revolution': Rhetoric and reality. Pro-Poor 698 Livestock Policy Initiative, 1-23.

699 Singhal, K.K., Mohini, M., Jha, A.K., Gupta, P.K., 2005. Methane emission estimates from

700 enteric fermentation in Indian livestock: Dry matter intake approach. Curr. Sci. India 88, 119701127.

702 Stott, A., MacLeod, M., Moran, D., 2010. Reducing greenhouse gas emissions through better 703 animal health. Policy Briefing: Rural Policy Centre Scottish Agricultural College, 1-8.

704 Swamy, M., Bhattacharya, S., 2006. Budgeting anthropogenic greenhouse gas emission from 705 Indian livestock using country-specific emission coefficients. Curr. Sci. India 91, 1340-1353.

706 Global methane emission from livestock and poultry manure. In: USEPA (Ed), US

707 Environmental Protection Agency, Washington DC.

708 Webb, J., Audsley, E., Williams, A., Pearn, K., Chatterton, J., 2014. Can UK livestock

709 production be configured to maintain production while meeting targets to reduce emissions of 710 greenhouse gases and ammonia? Journal of Cleaner Production 83, 204-211.

711 York, L., Heffernan, C., Rymer, C., 2016. The role of subsidy in ensuring the sustainability of 712 small-scale anaerobic digesters in Odisha, India. Renew. Energ. 96, 1111-1118.

713 York, L., 2017. The Impact of Climate Change on Poor Dairy Producers ub Odisha, India.

714 School of Agriculture, Policy and Development, University of Reading, Reading, UK p. 451. 